\title{
МЕРЫ ДОВЕРИЯ В ВӦЕННОЙ ОБЛАСТИ. ПОНЯТИЕ, СУЩНОСТЬ И СОДЕРЖАНИЕ
}

\author{
A.В.Шепе льский *
}

В международных отношениях доверие всегда играло важную роль. Его наличие или отсутствие нередко оказывало влияние на решение вопросов войны и мира. С ним традиционно связаны представления о безопасности. По мере совершенствования средств ведения войны вопрос о доверии выходит в ряд приоритетных.

Само значение понятия доверия предполагает, согласно словарю русского языка, «убежденность в правоте, честности, добросовестности, искренности кого-либо; вытекаюшее из этого чувства соответствуюшее отношение к кому-; чему-либо».

Очевидно, что всеобъемлющая безопасность может строиться и цементироваться только на уверенности государств в том, что они могут доверять друг другу настолько, чтобы решать любые свои дела без обрашения к силе или $\mathrm{x}$ угрозе силой, сосуществовать в безъядерном, ненасильственном и в итоге демилитаризованном мире. В этих условиях проблема доверия приобретает новое измерение, ибо его укрепление между государствами - одна из принципиальных основ всеобъемлюшей безопасности; система же мер укрепления доверия относится в основном $\mathbf{x}$ военно-политической основе международной безопасности.

Одним из важнейших этапов решения этой задачи являются разработка и становление концепции международно-правовой модели мер доверия в военной области. Укрепление доверия обусловлено широчайшим спектром самых разных факторсв, действующих в сфере международного общения и влияющих на характер взаимоотношений государств. Но есть одна область международных отношений, в которой доверие имеет особо важное значение, - военная. И это вполне закономерно. В военной области самым непосредственным образом соприкасаются, сталкиваются и переплетаются важнейшие интересы безопасности различных государств, зачастую входящих в противостоящие военные союзы. В ней же складывается и баланс интересов международной безопасности, являющейся одним из краеугольных камней развязки напряженности и взаимовыгодного сотрудничества. От наличия или отсутствия доверия между государствами в военной области во многом зависит ослабление или уснление опасности возникновения вооруженных конфликтов.

* Каңдкдат юридических наук, преподаватель хафедры теории и истории государства и международного права Военного университета. 
В Дипломатическом словаре меры доверия определены как «коллективные и односторонние акции государств, предпринимаемые в целях содействия уменьшению военного противостояния и напряженности, а также предотврашения всзникновения вооруженных конфликтов вследствие неправильной оценки военной деятельности друг друга (военные учения, передвижения войск и т.д.)».

В Кратком политическом словаре предлагается следующее определение: «Меры доверия - коллективные и односторонние акции государств, п्редпринимаемые в политической, военной, экономической и социальной областях в целях укрепления международного мира и безопасности, роста доверия и взаимопонимания между странами, содействия прогрессу в области разоружения, уменьшения военного противостояния и напряженности, а также предотвращения возникновения вооруженного конфликта вследствие неправильной оценки намерений и военной деятельности друг друга».

Выработкой определения понятия мер доверия, раскрытием его содержания занималась и Организация Объединенных Наций. Прежде всего следует указать, что Устав ООН в числе ее основных целей определяет поддержание международного мира и безопасности, а также развитие дружественных отношений и сотрудничества мехду народами; ООН призвана быть центром для согласования действий наций в достижении этих целей, которые в значительной степени совпадают с целями мер доверия. Поэтому естественным было то пристальное внимание, которое ООН уделяла этому новому мехдународно-правовому институту и с самого начала активно содействовала разработке и согласованию мер доверия как на региональном, так и на глобальном уровнях.

Очевидно, что некоторые меры по укреплению доверия могут содействовать достижению конкретных целей ООН, которая, со своей стороны, может стимулировать процесс укрепления доверия и совершенствовать механизм осуществления актуальных мер доверия. Прежде всего, ООН поддерживает процесс укрепления доверия в области разоружения; она неоднократно обсуждала вопрос об открытости военных бюджетов; оказывает помощь государствам членам ООН в обмене необходимой информацией. ООН направляет государствам-членам информацию о соблюдении положений договоров о химическом и бактериологическом оружии, о морском дне и др.

Организация Объединенных Наций рассматривает меры доверия в непосредственной связи с разоружением. Но, с друтой стороны, в мерах укрепления доверия нельзя видеть альтернативу разоружению. При обсуждении этого вопроса в ООН прямо указывалось, что «меры по укреплению доверия не долхны являться 
ни заменой, ни предварительным условием для разоружения или для переговоров по разоружению и не должны отвлекать внимание от необходимых мер в области разоружений». По моему глубокому убеждению, меры доверия в военной области неразрывно связаны с проблемой разоружения. Ничто не может содействовать успешному решению проблемы разоружения так эффективно, как меры доверия. Это единый процесс. Разрывать его алогично.

Таким образом, сущность и содержание понятия «меры доверия» определяются, по сути дела, их целями и принципами, которые вместе с конкретным содержанием этих мер довольно определенно их характеризуют, дают общее представление об их значении в деле решения важнейших проблем современных международных отношений.

Поэтому меры доверия в военной области можно определить как совокупность конвенционных и обычных норм международного права, регулируюших отношения между государствами в военной области и призванных исключить обострение отношений между государствами или возможность возникновения вооруженного конфликта, явившихся результатом неправильного понимания или неправильной оценки военной деятельности других государств.

Что касается юридической природы и юридической силы международно-правовых актов, закрепляюших нормы и принципы, регулирующие меры доверия в военной области, то следует обратить внимание на следующее.

Анализируя юридическую природу мер доверия в военной области, необходимо подчеркнуть, что своеобразие ее заключается в том, что международно-правовые нормы, которые их регулируют, подразделяются на две группы.

Первая группа - это нормы, непосредственно регулирующие меры доверия в военной области, такие хак Заключительный акт и Итоговый документ Стокгольмской конференции по мерам доверия.

Вторая группа - это нормы, регулируюшие меры доверия, которые закреплены в качестве сопутствующих мер в международных договорах и соглашениях, хасағщихся безопасности и разорухения, таких как Соглашение о мерах по уменьшению опасности возникновения ядерной войны между СССР и США (1971 г.); система соглашений, подписанных СССР с США (1972 г.), с Великобританией (1986 г.), с ФРГ (1988 г.) и с Францией (1989 г.) «о предотврашении инцидентов в отхрытом море и в воздушном пространстве над ним»; Договор между СССР и США по РСД-РМД (1987 г.) и др.

Подводя итог сказанному, можно сформулировать цели мер доверия в военной области следующим образом: 
- укрепление международного мира и безопасности, содействие предотврашению войн и вооруженных конфликтов, осбенно ядерной войны. Цели мер доверия должны быть направлены на укрепление стабильности или восстановление равновесия в периоды напряженного международного противостояния;

- создание благоприятных условий для мирного разрешения существующих международных проблем и споров и для улучшения развития международных отношений на основе справедливости, сотрудничества и солидарности, а также для облегчения урегулирования любой ситуации, которая могла бы привести к возникновению трений в международных отношениях;

- реализация принципов, изложенных в Уставе ООН;

- уменьшение или даже устранение причин недоверия, опасений, неправильного понимания и неправильной оценки того, что касается военной деятельности и намерений других государств, факторов, которые могут породить чувство ослабления безопасности и послужить оправданием для продолжения наращивания вооружений на глобальном и региональном уровнях;

- содействие предотвращению военной конфронтации, а также скрытой подготовки к развязыванию войны, уменьшение опасности внезапных нападений или случайного возникновения войны и, наконец, осуществление и конкретное воплощение на этой основе основополагаюшего принципа международного права воздерживаться от угрозы силой или ее применения во всех формах;

- с учетом возросшего понимания важности соблюдения международно-правовых обязательств меры доверия могут облегчить проверку выполнения соглашений в области ограничения вооружений и разоружения; они должны относиться $\mathrm{K}$ деятельности вооруженных сил, а не к их потенциалу;

- соглашения о мерах укрепления доверия должны основываться на предпосылке о том, что заинтересованные государства желают избежать конфликта, однако, учитывая возможность отхода от этой предпосылки, важно обеспечить, чтобы такой режим безопасности предусматрівал меры контроля, необходимые для предотвращения или обнаружения обмана.

Таким образом, взаимосвязь и взаимообусловленность основных принципов мехдународного права и специальных принципов мер доверия в военной области позволяют выделить совокупность мер по укреплению доверия в военной области в качестве связующей с бшим международным правом совокупности правовых норм, с одной стороны, и определить их в качестве самостоятельного международно-правового института - с другой.

Кроме того, необходимо указать на юридическую силу проанализированных принципов и обязательство государств соблюдать их 
в своих взаимоотношениях. Как отмечается в Кодексе поведения государств, принятом на Будапештской встрече глав государств и правительств стран - участниц ОБСЕ в декабре 1994 года, полное уважение всех принципов СБСЕ, а также добросовестное выполнение всех обязательств, принятых в рамках ОБСЕ, имеют основополагающее значение для стабильности и безопасности и, следовательно, представляют непосредственный и законный интерес для всех государств-участников, а в Политической декларации, принятой на этой же встрече, страны-участницы со всей решимостью заявили, что они вновь подтверждают принципы, закрепленные в хельсинкском Захлючительном акте и последующих документах СБСЕ. Эти принципы являются отражением общих ценностей, которыми необходимо руководствоваться при осуществлении своей политики, индивидуально и коллективно, во всех организациях и институтах, в работе которых участвуют государства.

При интерпретации хахдого из принципов необходимо исходить из единства всех этих принципов. Нельзя абсолютизировать ни один из них в ущерб выполнению других. Если какой-либо из принципов наделяет участника международных соглашений по мерам укрепления доверия правами, то одновременно он становится для него обязательством выполнять положения всех других принципов.

Раскрьів понятие, сушность и содержание мер доверия в военной области, хотелось бы сделать следующие выводы.

Во-первых, анализ международно-правовых актов, закрепляющих меры доверия в военной ббласти, позволяет выявить тенденцию развития данного международно-правового института. Первоначально меры доверия сводились ' $\mathrm{K}$ установлению связи между государствами (соглашения о «горячей связи»), $\mathbf{x}$ беспечению навигационной безопасности (соглашения о предотвращении инцидентов). Затем меры доверия стали включать уведомления и информацию о военной деятельности, об обмене военными наблюдателями и инспекциями на местах. Далее. Государства, заключая договоры о мерах по ограничению вооружений, стали наделять создаваемые ими органы контроля функциями по укреплению доверия.

Меры доверия 1960-1970 годов были в основном направлены на предотврашение вооруженных хонфликтов с применением ядерного оружия; позже они были направлены на снижение риска вооруженного столкновения с участием обычных вооруженных сил.

И наконец, по мере развития института мер укрепления доверия меняется юридическая сила источников, в которых они закрепляются. Если Захлючительный (хельсинкский) акт имел юридическую силу, упор в нем делался на добровольное осуществление его 
положений; в последующих ахтах акцент делается на том, что их решения политически обязательны.

Заметные изменения в отношении мер укрепления доверия произошли в России - от в целом негативного отношения $\mathrm{K}$ ним в дохельсинкский период, через признание их в Заключительном (хельсинкском) акте 1975 года до присоединения к программе НАТО «Партнерство во имя мира» в 1994 году.

Во-вторых, меры доверия в военной ळбласти хотя и имеют узкую направленность, однако их нельзя ограничивать только проблемами вооружений и вооруженных сил. Специфика мер доверия состоит в том, что они охватывают весь спектр политики и практики всех государств; поэтому сводить всю проблему доверия только лишь к военной области было бы совершенно неверно. Вместе с тем именно доверие в военной области является доминирующим в понятии мер доверия.

Относительно содержания мер доверия следует заметить, что они сами по себе не обязывают государства осуществить разорухение, ограничить гонку вооружений и т.д., но способствуют преодолению неверных суждений о намерениях другой стороны, снятию подозрительности и укреплению взаимопонимания.

Меры доверия создают благоприятные условия для осуществления реального разоружения и ограничения гонки вооружений.

В-третьих, цели и принципы мер доверня следует рассматривать В органическом единстве. Сформулированные в документах ОБСЕ цели будут выполнены государствами-участниками в том случае, если их действия будут основаны не только на общих принципах мехдународного права, но и на специфических (отраслевых) принципах, относящихся к праву мехдународной безопасности.

Цель мер доверия и принципы их реализации направлены на то, чтобы упрочить международный мир и безопасность, способствовать созданию атмосферы доверия, большего взаимопонимания и более стабильных отношений мехду государствами.

Ках уже отмечалось, в рамках СБСЕ разработана вполне удовлетворительная система принципов. Есть решимость государств выполнять эти принципы. Однако этого нельзя сказать о методике их практического применения в современной Европе. Если даже тот или иной принцип СБСЕ сформулирован четко, то все равно процедуры и инструменты его реализации нухно вырабатывать для каждого отдельного случая.

В-четвертых, меры доверия в военной области - это детище СБСЕ (ОБСЕ). Однако деятельность ОБСЕ не ограничивается только проблемами мер укрепления доверия, она гораздо шире. Меры доверия в военной области - это одно из направлений деятельности ОБСЕ. По мере возрастания роли и влияния ОБСЕ на развитие 
мировых процессов будут возрастать роль и значение мер доверия в реализации проблемы разоружения, ограничения и сокрашения вооружений и вооруженных сил. ОБСЕ играет более заметную роль в осушествлении функций контроля за выполнением международных договоров по разоружению. Так, государства, подписавшие Пакт о стабильности в Европе от 21 марта 1995 г., возложили на ОБСЕ наблюдение за выполнением двусторонних договоров. Например, ОБСЕ получила мандат наблюдать за выполнением Российско-Латвийских соглашений о РЛС в Скрунде, о военных пенсионерах и др. Подобные примеры свидетельствуют о том, что за ОБСЕ большое будущее в плане установления мира и безопасности в Европе.

\section{ЛИТЕРАТУРА:}

Док.: Декларация государств - участников Договора о коллективной безопасности и Концепция коллективной безопасности государств участнихов Договора, 10 февраля 1995 г. // Дипломатический вестних. 1995. - № 3. - С. 33-37.

Заключительный акт Совещания по безопасности и сотрудничеству в Европе. Хельсинки, 30 июля - 1 августа 1975 г. - М.: Междунар. отношения, 1987. $-78 \mathrm{c}$.

Кодекс поведения, касающийся военно-политических аспектов безопасности, принятый на встрече глав государств и правительств стран участниц СБСЕ 6 декабря 1994 г. // Дипломатический вестник. - 1995. № $1 .-$ C. $14-18$.

Разоружение. Исследование 7. Всеобъемлющее исследование о мерах по укреплению доверия. - Нью-Йорк. ООН. 1987. VII. - 48 с.

Разоружгпие. Исследование 17 . Исследование по вопросу о сдерживании. - Нью-Йорк. ООН. 1987. VII. - 154 c.

Разоружение. Исследование 20. Исследование роли ООН в области контроля. - Нью-Йорк. ООН. 1991. XVII. - 89 с.

Пакт стабильности в Европе // Дипломатический вестник. - 1995. № 5. - C. $24-27$.

Партнерство ради мира: рамочньй дохумент от 10 якваря 1994 г. // Дипломатический вестник. - 1994. - № 13-14. - С. 32-33.

Словарь русского язька. В 4-х томах. - Т. 1. - М.: Русский язькк, 1985-1989. - C. 412.

Дипломатический словарь. В 3-х томах. - Т. II. - 1985. - С. 218.

Краткий политический словарь. - М., 1989. - С. 317. 